\title{
FUNCTION OF THE LARYNGEAL MUSCLES ON THE POSITION AND
}

\section{SHAPE OF THE VOCAL CORD}

\author{
YUICHI KOIKE, M.D., MINORU HIRANO, M.D., \\ MICHIHIRO MORIO, M.D. and TAKAO KASUYA, M.D. \\ The Department of Otolaryngology, School of Medicine, Kurume University, Kurume
}

(Director: M. Hirano, M.D.)

The purpose of the present study is to investigate how the position and the shape of the vocal cord are altered by contraction of the laryngeal muscles, and thus to determine the role of each laryngeal muscle in adjusting the vibrator, i. e. the vocal cord.

In excised canine larynges, the changes in position and shape of the vocal cord when each muscle was electrically stimulated were observed and photographed from above as well as from the inner side. Then the larynges were rapidly immersed in cold alcohol solution of $-30^{\circ} \mathrm{C}$ and fixed in the stimulated condition. They were dehydrated with a freeze substitution method, and later seved for histological examinations.

The results obtained are the followings:

1. Whe the the cricothyroid muscle is stimulated, the vocal cord is stretched, elongated and slightly adducted to paramedian position. The edge of the vocal cord becomes thin.

2. Contraction of the posterior cricoarytenoid muscle results in abduction of the vocal cord to lateral position and the glottis is widely opened. The edge of the vocal cord becomes slightly thick, however, it becomes thin in the width of the entire vocal cord.

3. Among the adductor muscles, there are significant differences in regulating shape of the vocal cord. When the thyroarytenoid muscle is stimulated, the vocal cord is markedly shortened and thickened and the middle part of the vocal cord is bulged. On the other hand, the cord is slightly elongated and becomes slightly thin at the edge when the lateral cricoarytenoid muscle is stimulated.

4. On the histological examination of frontal section of the vocal cord, size and shape of the subepithelial layer, i. e. lamina propria is changed by contraction of each muscle.

Contraction of the thyroarytenoid muscle results in an increase in cross sectional area whereas a decrease in the area results from contraction of the other three muscles.

5. Contraction of the arytenoid muscle causes adduction of the arytenoid region, however, it dces not affect shape of the membranous portion of the vccal cord markedly.

6. From the findings described above, it appears that the laryngeal muscles play important roles to change the shape of the vocal cord, as well as to determine the position of the vocal cord.

This gives us the bases to discuss laryngeal adjustments which produce different patterns of vocal cord vibration in various ways of phonation. 


\section{内 喉 頭 筋 の 機 能 \\ 一一声門および声帯形態の変化に関して——

久留米大学医学部耳鼻咽喉科学教室 (主任: 平野実教授)
小池 祐 一
粕谷 平尚男

\section{緒 言}

喉頭の生理機能の中でも人の発声機能は最も分化した 高等なものとされる. それだけにその機構は複雑であ り, 従つて, その主役を演じる内喉頭筋の機能について も,すべてが明らかにされているわけではない。内喉頭 筋の機能に関しては解剖学的, 組織学的, 生化学的, 生 理学的など, いろいろのアプローチによつて, 従来多く の研究がなされ，それぞれで多くの知見がもたらされて いる. 特に生理学的立場から筋の活動様式をみる筋電図 的研究が最も多く, かつ深く行われており, 最近では平 野1) が歌声の調節機構に関して, また広瀬) が発話時の 内喉頭笳活動に関して, 主として筋電図的に研究を行っ て, 発声機能といら立場から, それぞれの内喉頭筋の機 能の分化を詳細に解明している.

ところで発声時には, 主として内喉頭筋の活動によつ て, 声帯はその位置, 形態, 緊張度などが微妙に変化調 節され, それによつて声帯の振動モードや声帯音の性質 が規制される 声帯を振動体といら観点からみる時, 筋活動の結果生じる声門および声带形態の変化をそれぞ れの内喉頭筋について明らかにしておくことも, 前述の 筋電図研究とはまた別の立場から, 喉頭筋の性格を深く 解明し, 声帯の振動モードを理解する上で重要なことで ある. この方面の研究としては内喉頭筋作㗢時の声門形 態の変化に関するものがあり, 従来より摘出喉頭や生体 喉頭で多数の実験的研究が行われているが5(8)1114115), そ れらは岩村8)による犬生体喉頭における定量的観測を除 けば，大部分が平面的，定性的観察にとどまつており， 必ずしも充分とは言い難い.

われわれは犬摘出喉頭を用いて, 各内喉頭筋を電気刺 激し, その際の声門および声帯形態の変化を多面的にと らえ, さらに急速凍結固定喉頭を用いて, 声帯の内部構 造の変化を検討した. このよらな研究をする目的は複雑 な喉頭調節における内喉頭筋の働きを形態的な面から追
求する第一歩であり, まず基本像として内喉頭筋単独作 倒の場合の声門および声帯形態の変化を明らかにし，む つて内喉頭筋の機能を機能形態学的立場から研究しよう とするものである.

\section{研究対象および方法}

研究材料には新鮮な犬摘出喉頭を使用した. イソゾー ル静脈麻酔下に成犬喉頭を速やかに摘出し，喉頭蓋およ び仮声帯を切除して声帯が完全に明視されらる状態にし た. さらに各内喉頭筋, 寸なわち輪状甲状筋(前筋), 甲 状披裂筋 (内筋)，側輪状披裂筋 (側筋)，後輪状披裂筋 (後筋) および披裂筋（横筋）を損傷させることなく露 出させた。なお内筋および側筋は外部より直視できない ので，甲状軟骨板に長方形の開空を行って明視下にお き,さらに両筋の間を走る反回神経内転筋枝を切除し て, 直接に筋のみが電気刺激されらる状態とした（図 1).

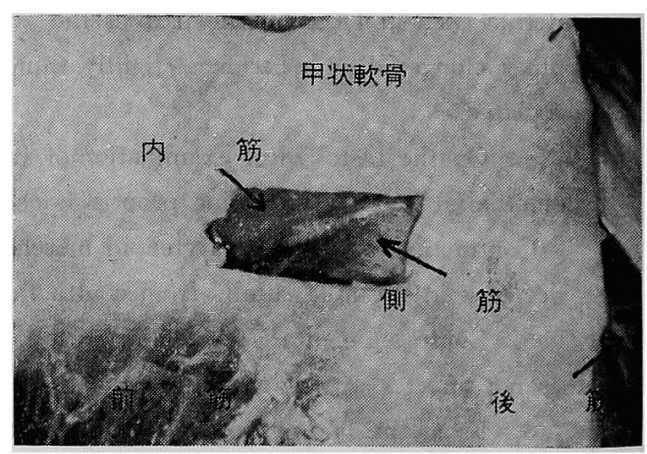

図 1 内喉頭筋の露出

以上の処置を終えた喉頭 (以下処置済喉頭と称する) の輪状軟骨下端部を固定台あるいは固定棒で支持固定し て，一側内喉頭筋にそれぞれ単独に電気刺激を行い，そ の際の声門および声帯形態の変化を以下に述べる方法に よつて観察した，電気刺激は日本光電製刺激装置を使用 
して，双極電極をそれぞれの笳のほぼ中央部にあてがつ た. 刺激の条件は電圧 $4 \sim 6 \mathrm{~V}$, 頻度 $30 \mathrm{~Hz}$, 持続時閒 1 msec である.

なお内喉頭筋 5 つのうち，横筋刺激では声帯形態の変 化が非常に柽微であり，われわれの実験方法ではその変 化を捉え難いため，寒験の大部分では，これを除く残り 4 筋を対象とした．観察の方法は下記の 4 つである.

1）声門上よりの観察

2）声門内側上りの観察

処置済喉頭をさらに正中矢状面で切断した半截喉頭を 用いて，声門内側よりその変化を観察した．

なお1)，2)の実験では, その変化をすべて喉頭抽よび カメラを固定した状態で写真に記録し，声帯の位置，長 さ，厚み，声帯上縁のレベルおよび声門面積のそれぞれ の変化を検討した。

3）凍結固定喉頭の鋳型による観察

処置済喉頭の輪状軟骨下端部をクリップ付固定棒で支 持固定し，一側内喉頭筋を電気刺激したそのままの状態 で, 一30 Cに冷却した100\%アルコール液に瞬時に浸し て, 急速凍結固定を行つた（図 2, 図は半截喉頭の場合 を示寸). 次いで，同冷却アルコール液に浸したまま $-30^{\circ} \mathrm{C}$ の冷凍庫に移し， $5 \sim 7$ 日間加けて喉頭組織の 凍結置換固定を行い，その後徐々に室温にもどした，そ こで固定された呢頭をアルコール液より取り出しそその 内腔へ印象剤アルジェースを注入して, 喉頭内腔の鋳型 を作製し，特に声帯中央部の前額断錹型像によつて声門 および声帯形態の変化を検討した。

4) 凍結固定喉頭の組織像による観察

半截喉頭を用いて3）と同稼の実験を行い，凍結固定喉

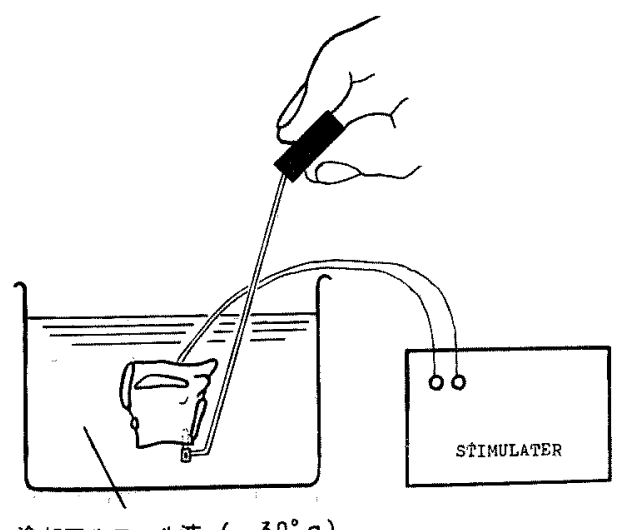

冷却アルコール液 $\left(-30^{\circ} \mathrm{c}\right)$

図 2 急速凍結固定実験方法
頭より声带中央部の前額断組織片を切り出し，パラフィ ン包埋大切片標本 $(10 \sim 15 \mu)$ を作製，H. E. 染色挍 よび恣原・弾瀪維染色を行って，声帯内部の構造の変 化を組織学的に検討した，な报反対側の半截喉頭位無刺 激のまま同様の急速凍結固定により組織標本を作製して 対照とした。

\section{研究成績}

I 声門上および内側よりみた声門および声带形態の 変化

各内喉頭筋電気刺激時に招ける声門および声帯形態の 变化をまとめて示すと写真 1 の如くである. 以下具体的 にそれぞれの変化について順次述べる.

1）声帯位招よび声門面積の变化

非半截喉頭を用いて声带位の変化についてみると，写 真 1 , 表 1 に示卞如く, “前筋制激の場合には, 声带は軽 度の内側移動を行つて副正中位をとる。この場合の声帯 位の変化は声帯の伸長仁伴う附随的な位置移動であり， 䈯密には内転とは言えない内筋抒よび側筋刺激では， 声帯は強く内転して正中線を越え過内転位をとるが，そ の声带縁の形態は両筋で異なる，すなわち，内筋刺激の 場合には，声帯は主として膜様部が強く内側一膨出し， 弓状の声带縁を呈するが，軟骨部の内転は弱い，一方， 側筋刺激の場合には，声帯突起部が強く内旋するため， 膜様部および軟骨部はともに強く内転する。この場合， 声带縁は直線状をなし，内筋刺激の場合とは非常に対照 的である．横筋刺激では主として軟骨部が内転して声帯 は副正中位をとる．また後筋刺激では声帯は強く外転し て外側位をる。.

次に，声闍面積は声門上より撮影した写真を用いて， 両声带および両披裂部で囲まれた範囲の面積として計測 検討した，その変化は表 1 亿示す如くで，刺激前に対す る刺激中の面積の比（\%) で表わしている.

声 1 带位扔よび声門面積の変化

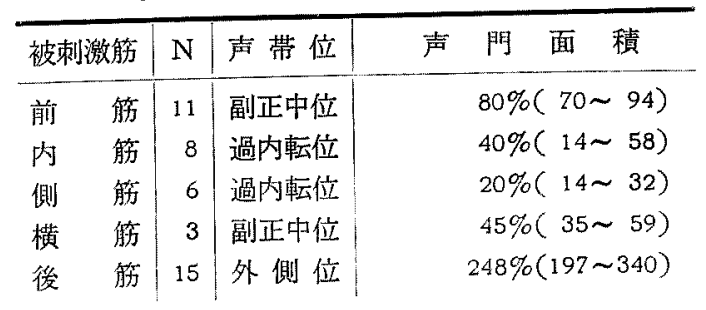

（註） $\mathrm{N}$ : 対象数 数值は一側内喉頭筋刺激時の刺激前に対する 刺激中の計測值の比 $(\%)$ 
まず，前筀，内筋，側管，横筋刺激の場合には，いず れも声門面積は減少し, 後筋刺激の場合のみ著しく増加 する．減少をきたす 4 筋についてみると，側筋刺激の場 合が最も声門面積の減少度が大きく $(20 \%)$ ，次いで内筋 刺激 (40\%)，横筋刺激 (45\%) の場合の順であり，これ ら3筋の刺激ではいずれも50\%以下に面積は減少してい る。前筋刺激の場合には，その減少度は最も小さく $80 \%$ である.

声門面積の変化は声帯位の変化を反映するものではあ るが，実際には，写真 1 でみられる如く，声帯緑が必ず しも直線状をなして変化しないことや, 声帯膜様部と軟 骨部とでは声門面䅡の変化度が異なることなどから，声 門面積の変化と声带位の変化とは必ずしも量的な比例関 係を示さない，内筋および側筋を例にとると，内筋刺激 では膜様部声帯縁が弓状に膨隆するため，声門乾骨部に 比して声門膜様部の方が面積の減少度は著しい一方, 側筋刺激の場合には，披裂軟骨が強く内旋するため，む しろ声門軟骨部面積の方がその減少度は小さい

2)声帯上縁の傾斜㧍よびレベルの変化

半截喉頭を用いて，声門内側より撮影した写真上で計 測した声带上緑の傾斜抢よびレベルの変化を示すと表 2 の如くである．表中に示寸角度は刺激前を水平とした場 合の刺激中の攧斜角度を示寸

表 2 声帯上縁の傾斜括よびレベルの変化

\begin{tabular}{|c|c|c|c|c|c|}
\hline 破刺激动 & $\mathbf{N}$ & 傾斜角 & 候 位 & & 声鱼レヘル \\
\hline 前 施 & 3 & $5^{\circ} \quad(5 \sim 6)$ & 前傾位 & - & 低下 \\
\hline 内 觔 & 3 & $14^{*}(12 \sim 15)$ & 後梿位 & $\ldots \ldots \ldots \ldots$ & 低下 \\
\hline 倒 筡 & $\mathbf{3}$ & $6^{\circ} \quad(5 \sim 7)$ & 啳傾位 & $-1 . \ldots$ & 低下 \\
\hline 後 筇 & 3 & $11^{\circ}(11 \sim 13)$ & 前傾位 & $\longrightarrow \ldots$ & 上丹 \\
\hline
\end{tabular}

前笳刺激では声帯上縁は声带前部が低位の前僋位 $\left(5^{\circ}\right)$ をとり，声帯全体は低下する，内筋刺激の場合には，声 帯前部が高位の後傾位 $\left(14^{\circ}\right)$ をとるが，声带全体として は最む低下寸る。亦た側解刺激では声带後部が低位の後 傾位 $\left(6^{\circ}\right)$ をとり，声带全体怯低下する，後筋刺激では 声带後部が高位の前傾位 $\left(11^{\circ}\right)$ をとり声带全体は上界す る. 声带上縁の傾斜の程度は前筋, 側筋刺激では小さ く, 内筋, 後筋刺激の場合には大きい

また，非半截喉頭に招いて，声带膜様部中央の声带上 縁のレベルを刺激側と非刺激側とで比較してみると，前 筋, 側筋刺激の場合には, 刺激側のレベルは低くなり，
内筋，後筋刺激の場合には高くなる．その変化の程度は 内筋，後筋刺激の場合がより顕著である。

内笳刺激の場合，声帯上縁のレベルが刺激側で高くな るのは, 声帯膜様部中央の著しい膨出による相対的上昇 であり, 声帯全体のレベルは前述の半截喉頭による観察 で明らかな如く，実際には低下している。

3)声帯の長さの変化

非半截喉頭を用いて，一側内喉頭筋を単独に電気刺激 した場合の声帯の長さの変化を示すと表 3 の如くである. 声帯の長さは前連合部より声帯突起むでの距離として, 声門上より撮影した写真上で計測し，その変化を刺激前 に対する刺激中の声帯の長さの比(\%)で表わしている.

表 3 声帯の長さの変化

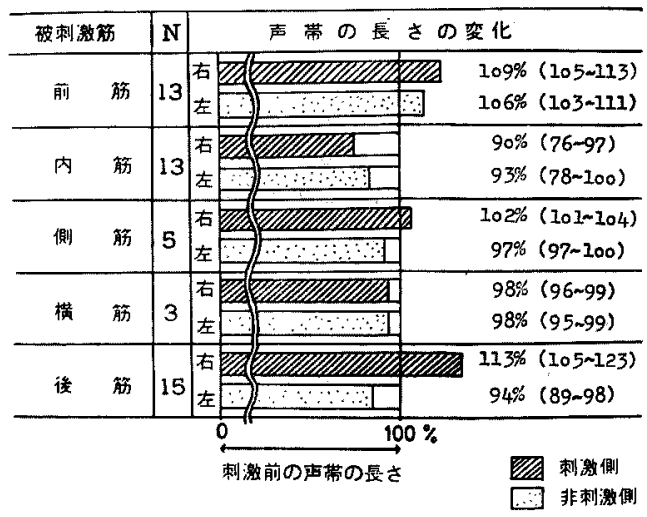

(注) $\mathrm{N}$ : 対象数

数值は一側内喉頭笳刺激時の刺激前に対する 刺激中の計測值の比 (\%)

まず, 刺激側声帯の長さの変化についてみると, 前 筋, 側筋, 後筋刺激の場合には, いずれも声帯は延長 し，内筋，横筋刺激の場合に洁声帯は短縮する。声帯を 延長させる 3 筋の中では，その延長の程度は後筋刺激の 場合が最も大きく，次いで前筋刺激の場合であり，側筋 刺激の場合には声帯の延長は非常に軽微である。一方， 内筋刺激の場合には声帯は著しく短縮する，横筋刺激の 場合の短縮は非常に軽微である。

次に, 非刺激側声帯の長さの変化についてみると, 前 筋刺激の場合のみ声帯は延長し, 他の内筋, 側筋, 杵 筋，後筋刺激の場合には声帯はいずれる短縮する，つま り，一側内喉頭筋を電気刺激すると，刺激側の声帯のみ ならず非刺激側の声帯の長さにも相当の変化が生じるこ とが明らかであり，しかも，前筋，内筋および横筋刺激 
表 4 声帯粘膜の組織形態的変化

\begin{tabular}{|c|c|c|c|}
\hline & 声带辺椽部の幅 & 声帯辺緣部の厚み & 声帯辺緣部の断面程 \\
\hline 前 䚣 & $94 \%$ & $108 \%$ & $90 \%$ \\
\hline 内 䉏 & 129 & 92 & 111 \\
\hline 側 筋 & 81 & 105 & 72 \\
\hline 嵝 能 & 95 & 91 & 93 \\
\hline
\end{tabular}

（註）数值は非刺激側（对照）に対する刺激側の計測値の比（\%）

の場合には，刺激側と非刺激側声帯とがともに，前筋刺 激では延長, 内筋および横筋刺激では短縮と一致した変 化をするのに対して，側筋および後筋刺激の場合には， 刺激側と非刺激側声帯とはいずれも一致した変化を示さ ない，つまり，刺激側声帯は延唇するのに非刺激側声带 は短縮する。この一見矛盾するが如き所見をきたす理由 について怔考按でふれる。

4）声帯の厚みの変化

声門上および内側の 2 方向から撮影した写真を用い て, 声帯の厚みの変化を検討した. 写真上での計測は困 難であるので，ここでは外観的変化の所見について述べ るにとどめる。

まず, 前笳刺激では声帯は強く伸長し，その辺縁部の 厚みは減少する．内篎刺激では，特に声帯膜様部におい て，その辺縁部は著明に厚みを增し，内側へ強く膨出す る所見が特長的である. 側筋刺激では声帯はやや伸長 し, 厚みを減して薄くなる。後筋刺激では, 声門上から 見ると，声带辺縁部は円みを帯びて，その厚みは增大す るが如く観察されるが，内側より見ると，声帯の下面で その鹪曲度を減じて平坦となり，厚みは減少している。 横筋刺激では声帯の厚みに関してほとんど変化を認めな r

\section{II 急速凍結固定喉頭における声門および声带形態の 変化}

各内喉頭筋電気刺激時における凍結固定喉頭の声門䥡 型像および組織像の変化をまとめて示すと写真 2 の如く である，以下に順次述べる具体的な変化は，最も定型的 に固定され，人工的変化の少ない代表的な各 1 例につい て観測したものである.
1）政型像よりみた変化

一側内喉頭筋雪気刺激時の淒結固定喉頭より作製した 声門鋳型から，声帯中央部における前額断鋳型像の変化 を各内喉頭筋についてみると，前筇刺激の場合には，刺 激側声帯は非刺激側声带に比して，その辺縁部は厚みを 減じてやや尖鋭化する，また声帯上縁のレベル恬やや低 くなるが, 声带下面から声門下腔にかけては，その形態 の変化はほとんど認められない.内筋刺激では声索辺緑 部は全体的にその厚みを著しく増大し，声帯上縁のレ心 ルはやや高くなる。これは声帯上面が強く膨出するため である、しかし声帯全体としてはそのレベルは低くなつ ており，声門下腔への移行部はその警曲度が著しくな る. 側筋刺激では声寡辺縁部の厚み法薄くなり, 声帯上 縁のレベルは低くなる，後筋刺激では声帯の辺縁部はそ の尖端部では晞みを增すが，声帯下面では平坦となり， 厚みは減少している、声帯下部加ら声門下腔にかけて は, その彎曲度は減少して, 滑らかな移行を示す 声帯 上縁のレベルは高くなる。

2) 組織像よりみた変化

急速凍結固定喉頭の声带膜様部中央に扔引る前額断組 織像冢写真 2 亿示す如くである. 組織像の桩大写真を用 いて，その組織形態上の変化を表 4 に示す如く計測検討 した．表中の数值は非刺激側（対照）に対する刺激側の 長さおよび面積の比（\%)を表わす。

(a)声帯辺縁部粘膜の幅の変化

声帯筋上端部のレベルで声帯辺縁部の翮の変化を見る 々, 前筋刺激の場合には，対照に比してわずかに減少 し, 内筋刺激では著しく増加している. また側筋刺激の 場合には, $81 \%$ と最も減少度が大きく, 後筋刺激ではわ 
ずかに減少している。

\section{(b)声帯辺縁部粘膜の厚みの変化}

声带辺縁部の最も突出した部位で上皮から声带筋まで の距離（声帯粘膜の厚みとする）の変化をみると，前 筋，側筋刺激の場合にはそれぞれわずかに增加してお り，内筋，後筋刺激ではそれぞれわずかに減少してい る.

以上の(a)，(b)の観測結果からみると（a)で測定した声 带辺縁部粘膜の幅の変化が前章で述べた外観上の声帯の 厚みの変化をよく反映していると言える.

(c)声帯辺縁部粘膜の断面積の変化

声帯辺縁部で上皮々声常筋の辺縁部とで国まれた範囲 （粘膜固有層に相当する）の前額断面皘の変化を榆討し てみると, 前筋, 側筋枋よび後筇刺激の場合には, いず れも断面積は減少し，内筋刺激の場合のみ著しく増加し ている.このような声帯粘膜の断面積の変化は声帯の外 観上の厚みの变化をその傾向においてよく反映してお り, しかも, その変化には粘膜固有層の形態的変化が主 に関与すると考えてよい

\section{総括および考按}

内喉頭筋は発声，呼吸，䀣下に関係した働きを有して おり, 特に発声には直接的に関与して喉頭の複雑な調節 を行つている. 内喉頭筋の機能は, 一般には声門開大 (後筋), 声門閉鎖 (内筋, 側管, 横筋) および声带緊張 (前筋)として大別分類されてはいるが，それぞれの管 の詳細な性格については，まだ完全には解明されてはい ない内喉頭筋の機能に関しては, その研究手段として 筋電図的方法が最も有力であり, 従来より多数の研究が 報告されているが, 最近の進んだ研究では, さらに声門 開鎖笳に関してその機能の分化が詳しく解明されつつあ $3^{124)}$.

われわれは本研究において内喉頭筋の働きを声門およ び声带形態におよぼす変化といら点から検討し，もつて 筋の機能を機能形態的に明らかにすることを目標とし た.この種の研究は従来より, 摘出喉頭や生体喉頭を用 いて多数の実験的研究がなされているが5)1114115)，それ らは声門形態の変化を平面的, 定性的に観察しているに とどまり，必ずしも充分とは言い難い内喉頭笳の作働 によって生じ声門形㿟の外観的変化, すなわち, 声帯 の位置, レベル, 長さ, 厚みの変化やさらに, 声帯内部 構造の組織形態的変化を明らかにすることは，前述の筋 電図的研究とはまた別の立場から, 内喉頭筇の性格をよ り深く理解し，さらに振動体としての声帯 ${ }^{228)}$ の振動モ
ードを理解する上でも重要なことである.

そこでわれわれは人喉頭に最も類低し，しかも入手し 易い犬摘出喉頭を用いて，内喉頭筋作働による声門およ び声帯形態の変化を立体的, 定量的, さらに声帯内部楛 造の変化についても組織学的に検討した次第である。

1）実験方法について

内喉頭筋の機能形態的研究を行う場合，摘出喉頭を用 いるか，生体喉頭を用いるかは実験の目的によつて多少 異なつてくるが，われわれの実験では声帯形態の変化を より明確に観測するため摘出喉頭を用いた. また半截喉頭 を用いて, 声門内側から钽測を行ったこと,ささらに声带 の組織形態的変化をみる目的に急速凍結固定法を店用し たことは従来の方法とは異なる点である。この方法は声 帯形態の reversible な変化を電気刺激中に冷却アルコー ル液に浸して急速に凍結し，同時に組織の㯰換固定をむ 件せ行おうとするものであるが，組織標本上でその形態 の変化を観測することは必ずしも容易なことではない．

つまり，組織標本作製の過程で, 人工的変形が加わり得 る可能性を否定しえないが，われわれは同一条件下の同 一喉頭 (片側) を対照として比較することによつて，で きるだけ真実に近い変化を得ることに努めた.

電気刺激の条件に予備実験で近接する筋に電流滑走を 起さない範囲で最も強い収縮を起させるに必要な最適有 効刺激条件を検討 $し, 4 \sim 6 \mathrm{~V}, 30 \mathrm{~Hz}, 1 \mathrm{msec}$ と一定 の条件とした．各笳の大きさや収縮力はそれぞれで異 なり，至適刺激条件は必ずしも一定ではないと考える が51516)，われわれの実験では上記の如く一定条件下での 筋の作働による変化をみることにした．電気刺激を行ら に際して最も注意を払つたのは選択的に単独筋のみを刺 激することであつた，問題となるのは内筋と側筋の場合 であり，われわれは筋を直接明視下におくとともに，神 経を切除して電流滑走を避けた. それでも両筋は相接し て存在するため, 両筋が誤つて同時に刺激されることが あるので，予耐筋について単独に電気刺激した場合の 声帯形態の特長的変化の違いを充分確認しておいた。 す なわち, 内筋を刺激すると, 声帯辺縁部は強く膨出して 厚みを增し, 声帯縁は弓状を呈して内転する. 一方, 側 筋刺激では声帯辺縁部は薄くなり, 声帯縁は直線的形態 を保って内転する．このように両筇は同じ内転筋でもそ の声帯形態に执よぼす作用は非常に異なるので, 正しく 单独の筋が刺激されているかどらかを形態的な面からも テェックしながら実験を進めた。

2）声門および声帯位の変化について 
過去の潪頭筋の機能に関する研究はこの点に関して枚 举にいとまがないほどの報告を行つているが, 声帯位の 定義は必ずしも明確ではない摘出喉頭によるわれわれ の実験でも，筋刺激による喉頭全体の変位, 他側声帯の 変位, 声帯形態の変化などが加わって, 声帯位の判定が 困難な場合が少くないが，一応ここでは従来の記載法に 準じている.

竹之内 ${ }^{15)}$ 注犬生体喉頭におるて，一側内喉頭筋支配神 経枝の電気刺激を行い，その声帯運動の観察結果から， 声門開鎖筋である横筋，側筋，声帯筋はそれぞれ過度内 転作用があるが，単独では声門閉鎖は起りえず，同時収 縮によつて始めて声帯の内転と声門闒鎖が完全になると 述べている．われわれの実験でも，内筋，側筋刺激では 同様に声帯は正中線を越えて過内転位を示したが，横笳 については，副正中位までの内転にとどまり，その内転 力は前 2 筋に比べてはるかに弱い 同じ過内転位をとる 内筋と側筋とでは，その声門像住非常に対照的であり， 内解の収縮では膜様部声帯は弓状に膨出した辺縁を呈 し，軟骨部声帯の内転は弱いが，側筋の収縮では膜様部 声帯は直線的辺縁を呈して，軟骨部声帯の内転は強い。 前笳が働くと声帯位は副正中位に移動し，声門面積も減 少するが，その作用は内転とは言い難く，声帯の伸長に 伴う附随的な内側移動と考えた方がよい. ${ }^{576)}$

声門開鎖筋について総括すると，内筋による過内転位 は声帯形態の著明な変化を伴う内転によるものであり， 側筋による過内転位は位置の変化を主とした内転による ものである.また横筋は軟骨部声門の閉鎖を主とした副 正中位への内転作用を有するが, 声帯形態にはほとんど 影響を与えない

\section{3）声帯のレベルの変化について}

半截喉頭による実験で声帯レベルの变化をみると, 内 筋刺激で声帯は最も著明に低下し, 声帯上縁の傾斜度む 最も大きくなる．前筋，側筋刺激では声帯レベルはわず が低下するのみであるが，声帯上縁の傾斜の方向は暴 なり, 前者では前傾位, 後者では後傾位をとる. 本実験 は摘出喉頭で輸状軟骨を固定して施行したものではある が，生体に打いても，その傾向としては，声帯レベルは 声門開鎖筋が働く発声時には低下し，後筋が働く呼吸時 には上昇すると考えられる。

非半截喉頭によつて, さらに喉頭内における相対的な 声帯上縁のレベルの変化をみると, 内筋を除く他 3 筋の 場合には半截喉頭における変化とその傾向は一致する が，内筋刺激の場合には声帯上縁のレベルは高くなり，
前述の半截喉頭での観察で声帯レベルが低下するとした 記载に反寸る. しかし，これ柱内筇刺激により膜様部声 帯の上面が膨出して, 上縁のレベルが相対的に上昇した 結果であり，声帯全体のレベルそのものは実際には低下 している.

4）声帯の長さの変化について

前笳は声带を延長させ，内管洋逆に短縮させることは 衆知のことである.このように両筋には相反する働きの あることから発声時に㧤ける声帯の緊張は兩筋によるも のであり，したがって雨筋を一括して声帯緊張筋とする ものもある゙、両筋が発声に重要な衔きをしていること は言らまでもないか⿱，声帯の長さの変化に関して，声門 閉銧筋である側筋，また開大筋である後筋については従 来あまり触れられていない，われわれの実験では側筋は わずかに，後筋は著しく声帯を延長させる働きがある。

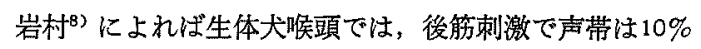
伸長, 側筋刺激では $7 \%$ 短縮すると述べており，われわ れの観測結果とは側筋において異っている，ところで声 帯の長さが変化すると, 当然, 声帯の祭張度に影響を与 えることになるから，その意味では側筋も後筋も声帯の 緊張を増す筋であると言える. 後筋は声門開大管である ことから，発声に㧍ける関与については未だ明確ではな いが, 声帯の緊張に関して, 前筋の声帯前方弯引に対す る後筋は後方牽引の意味を有し, 前筋の働きに拮抗して 披裂軟骨の支持の機能を有すると考えられる.

声帯の緊張度については，喉頭筋そのものの機械的収

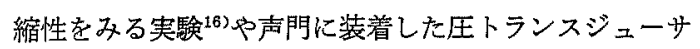

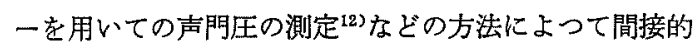
に声帯の毉張度を調ベることが行われている。われわれ 恃声帯振動との関係に主眼をおいているので，声帯全体 (粘膜と声帯筋) や声帯筋とは別に, 声帯粘膜のみの緊 張度の変化をむ問題としたいが，これを直接測定するこ とは現在のところ困難であり，声帯の長さや形態的変化 からその緊張度を推定している。

ところで一側内喉頭筋を電気刺激すると非刺激側の声 帯長にも影響がおよがことを前に述べた。このことは喉 頭の形態からみて予想されるところではあるが，特に側 筋おょび後筋の場合，刺激側声带は延長するのに非刺激 側声带は逆に短縮するといら相反する所見が認められ る.この理由について，側筋による短縮は非刺激側の披 裂部が刺激側へ率引され，声带突起尖端がわずかに内方 一移動するためであり，後筋による短縮は前連合部の後 方移動と披裂部が刺激側に率引されて, 声帯突起尖端が 
わずかに内方移動するためであると解釈している，摘出 喉頭でみられるこのような非刺激側の变化が生体喉頭で も同様に生じるかどらか問題であるが，生体喉頭注外喉 頭筋や周囲組織によつて支持固定されていることを考慮 すれば，その影㗽はより少いと考えられる。

5）声帯の厚みの変化について

内喉頭筋の收縮によつて声帯の厚みが変化することは 既に多くの記載があるが，特にこの点に焦点をしぽつて 検討された報告は少い，外観的には内筋刺激で声帯の厚 みは著しく增大し, 前管, 側筋, 後筋刺激では薄くなる が, 谏結固定組織像で検討してみると, 内筋刺激では声 帯粘膜固有層の断面積が増加しており, 前筋, 側筋, 後 筋刺激ではいずれも減少していることが分かる。これら の厚みの変化は声帯長の変化と闒連があり, 声带の延長 によって同面積は減少し, 短縮によつて増大している. また声帯辺縁部の厚みの計測から, 内筋刺激の場合には 声帯の厚みが増して両声帯の接触面は広くなり, 前筋, 側筋刺激では狭くなつている。これらの事実は発声時に おける声帯振動を理解する上で興味ある所見であり，前

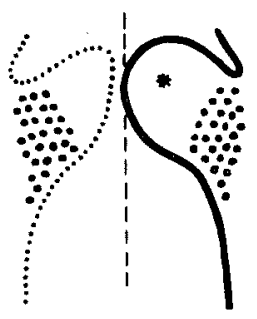

内 筋

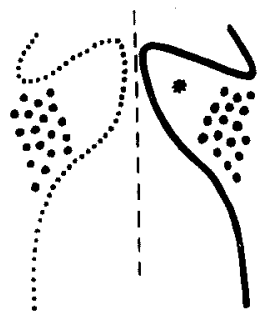

前 筋

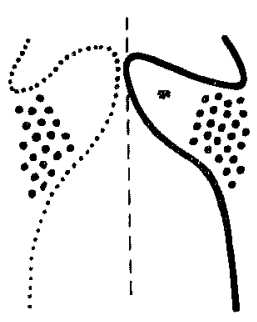

側 能

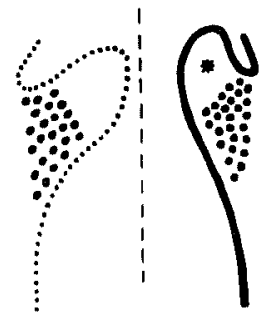

後 矨

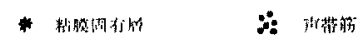

（注）実線は刺激側，点楾は非激側 (対熙)

図 3 内喉頭筇取縮時の声門および声带形態 (模式図)
筋が相対的に強く働く light register では粘膜波動や 振幅が小さく，一方，内筋が相対的に強く働く heavy register では粘膜波動，振幅が大きくなる所見 ${ }^{122}$ が良 く理解できる、また発声時の声帯振動は単に声帯の毉張 度のみならず, 声帯粘膜の厚みの変化，特に粘膜固有層 の変化が大きく関与していると考えられる.

6) まとめ

以上の声帯の位置, レベル，厚みに関する結果を総合 して, 一側内喉頭筋（横筋を除く）が作俉した場合の声 帯膜様部中央における前額断像の模式図を描くと図 3 の 如くなる.

最後に，内喉頭筋の機能を声門就よび声帯形態におよ ぽす作用といら点から整理してみると次の通りである。

1. 声带位の変化 副正中位……前筋，横筋 過内転位……内筋, 側筋 外 側 位……後筋

2. 声門の広さの変化

增加……後笳

減少……側筋 $>$ 内管 $>$ 横筋 $>$ 前筋

3. 声带のレベルの変化

上杽……後筋

低下……内筋 $*>$ 側筋 $>$ 前筋

4. 声帯の長さの変化

延長……後筋 $>$ 前筋 $>$ 側筋

短縮……内筋 $>$ 横筋

5. 声帯の緊張度**の変化

増加……前筋, 側筋, 後筋

減少........内筋, (横筋)

6. 声帯の厚みの変化

堌加 $\cdots \cdots$....内筋

減少……前筋, 側筋, 後筋

* 喉頭内における相対的声帯上縁のレベルは高くな る.

** 声带の緊張度は直接測定したものではなく, 形態 的变化を参考に推察したすのである.ここで言う㗨 張度は声帯㖘動漈して重要な声帯粘膜の stiffness と考えてよい

\section{結 語}

犬摘出喉頭を用いて，各内喉頭筋電気刺激による声門 および声帯形㿟心変化を立体的, 定量的,さらに組織形 態的に検討し，それぞれの内喉頭筋の機能を機能形態的 立場から明らかにした。しかし生体における内喉頭筋の 


$$
\text { 小池論文 付図 (1) }
$$

写真 1 内喉頭筋単独電気刺激時の声門および声带形態の変化

前 筋
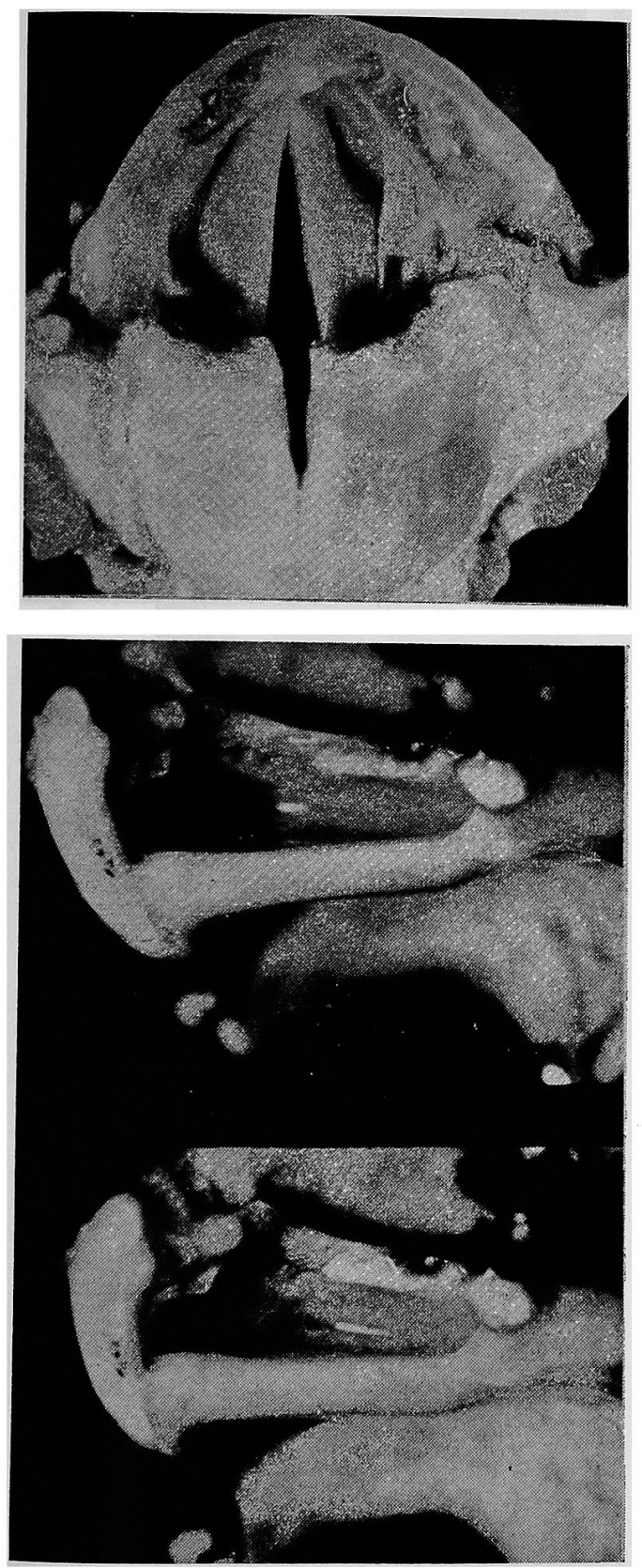

（注）上段の写真……刺激側は右側，下段の写真……方が刺激中，下が刺激前（対照）
内 管
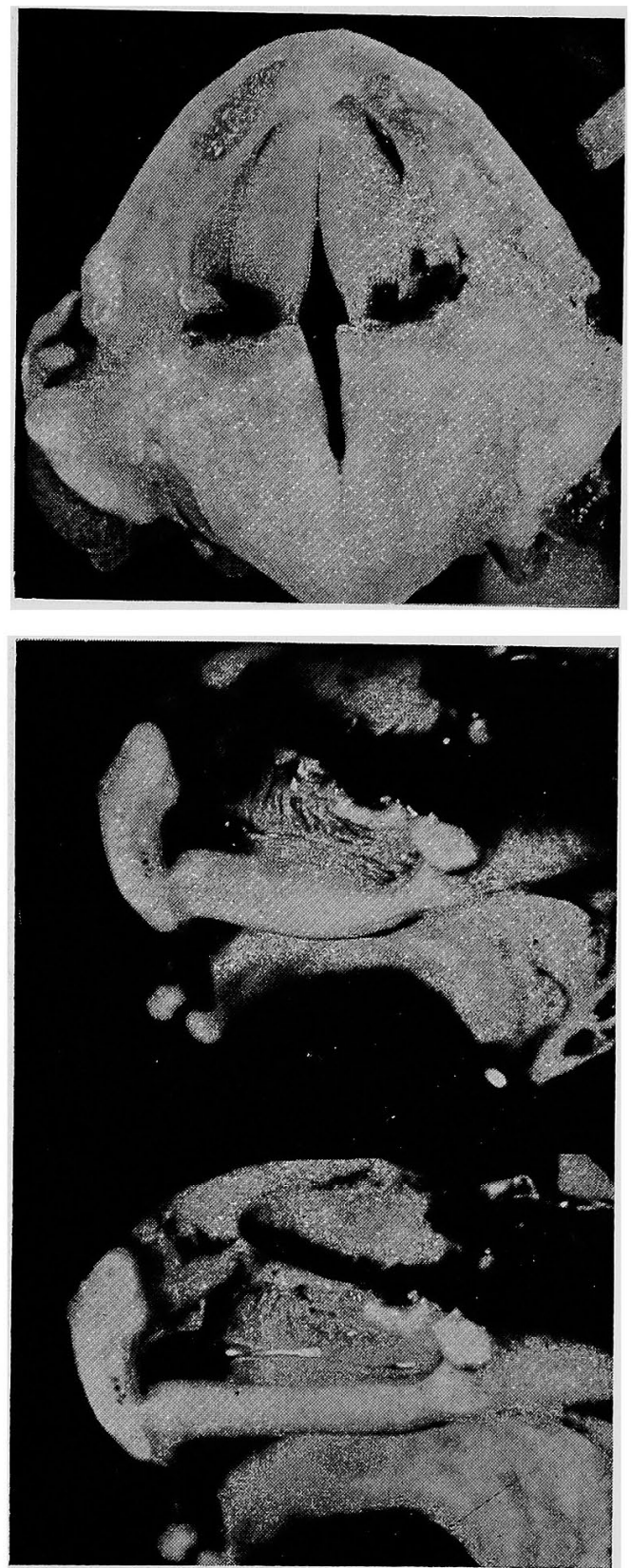
小池論文付図 (2)

側 筋
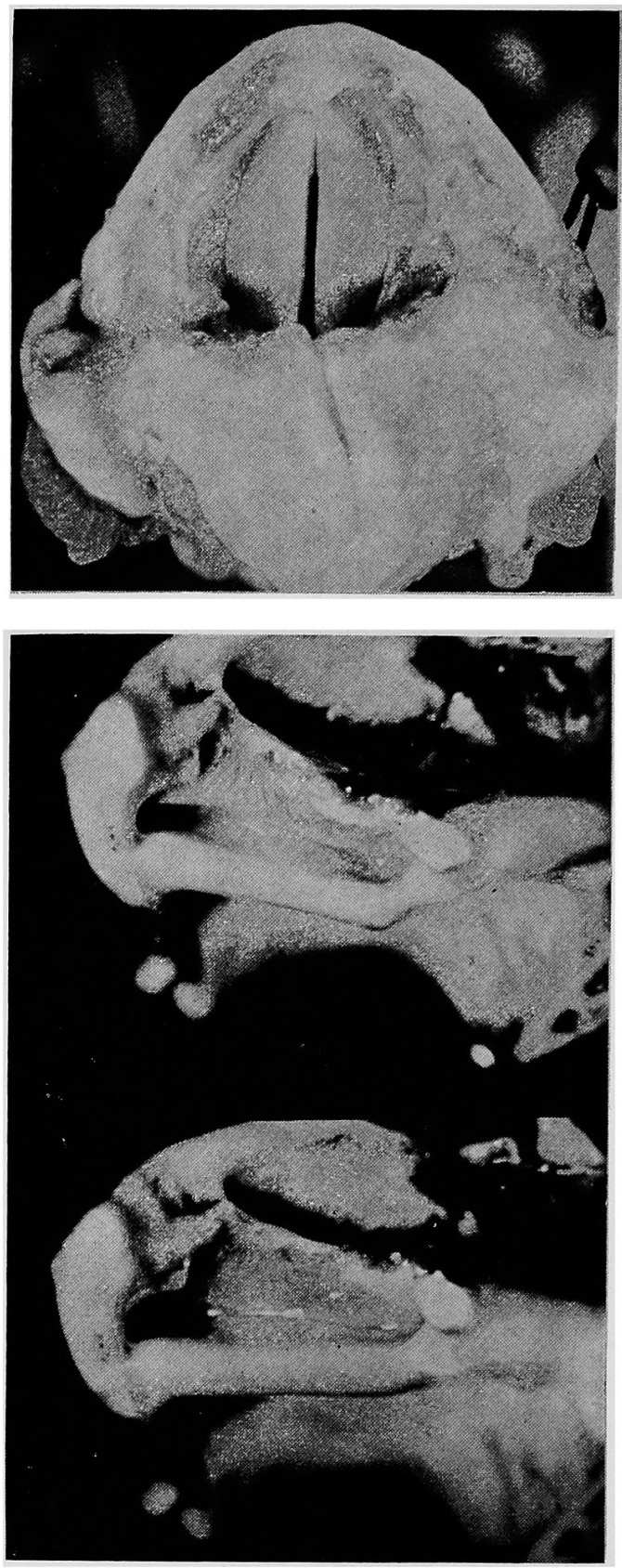

後 管
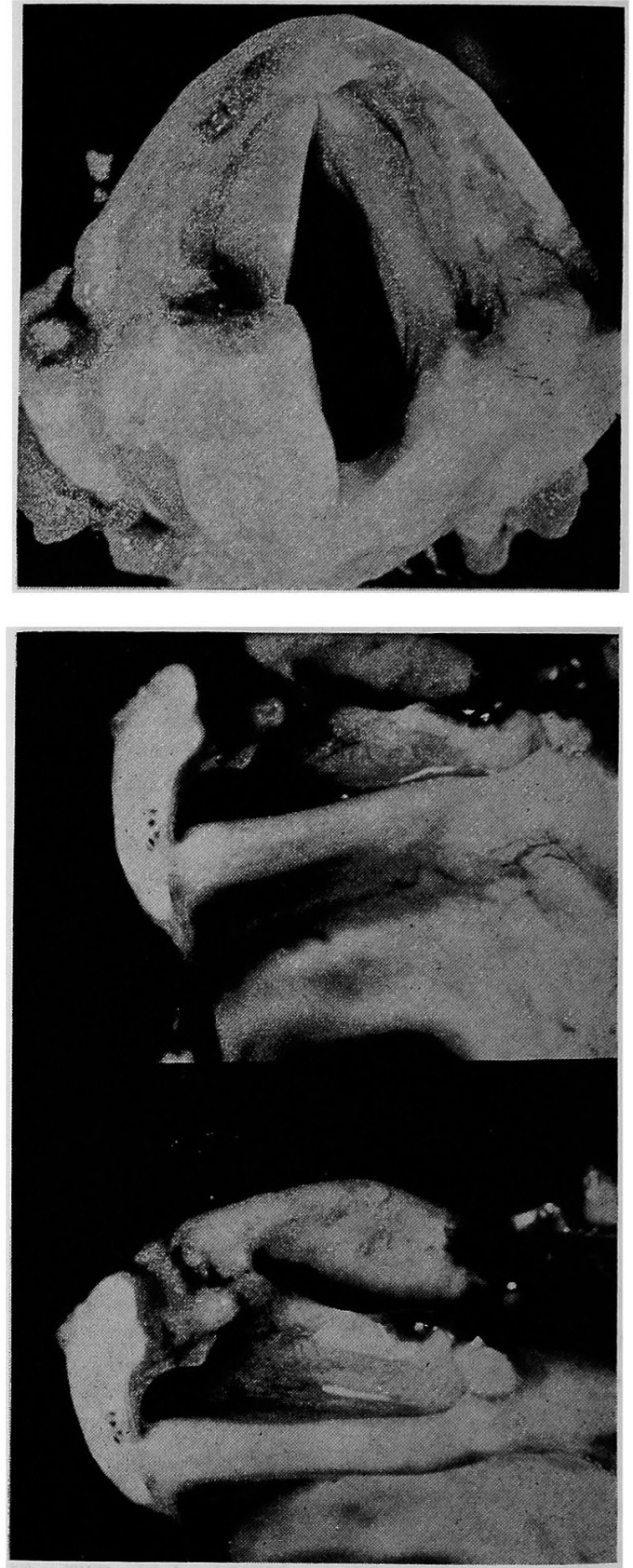
小池論文付図 (3)

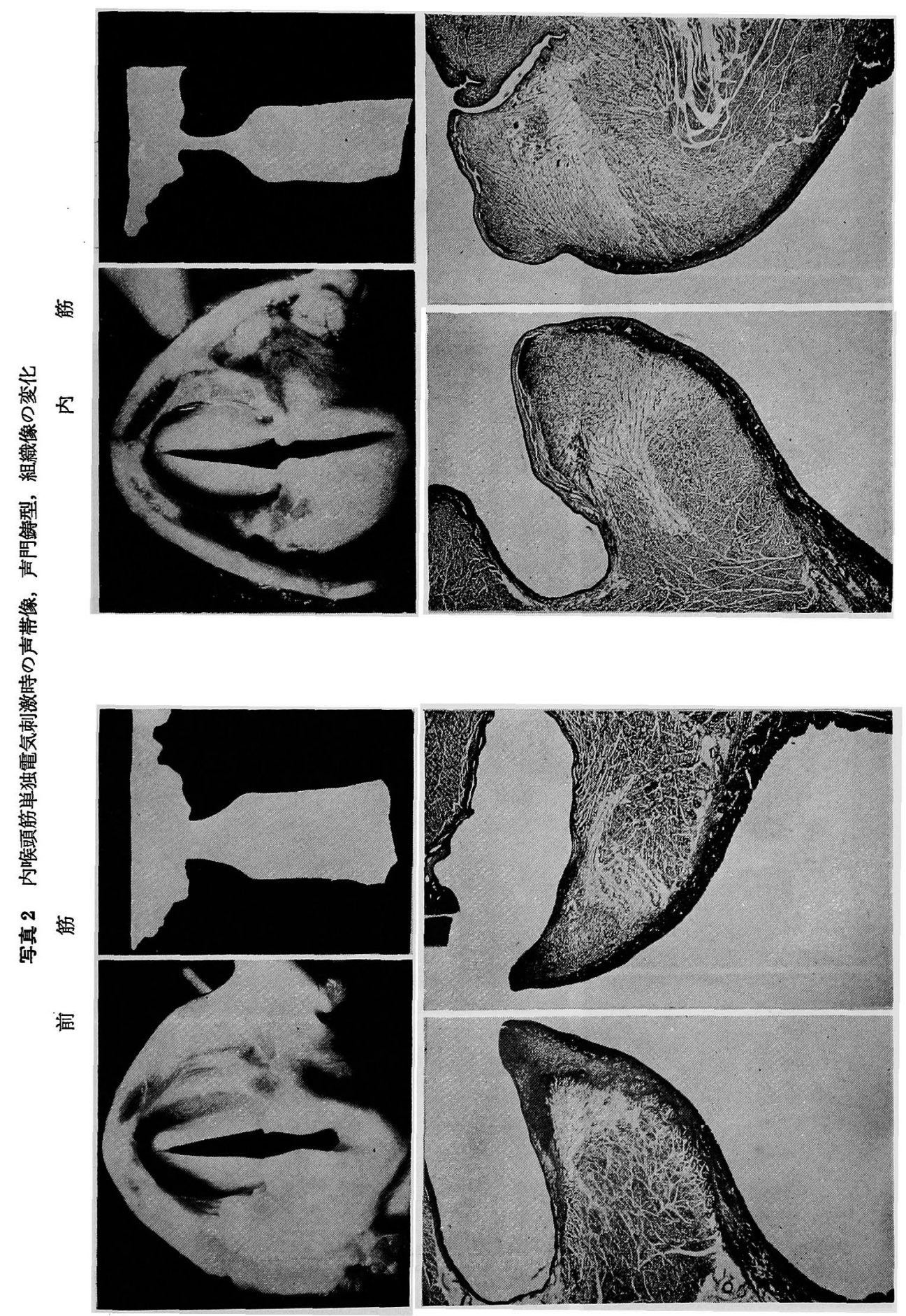


小池 論文 付 図 (4)
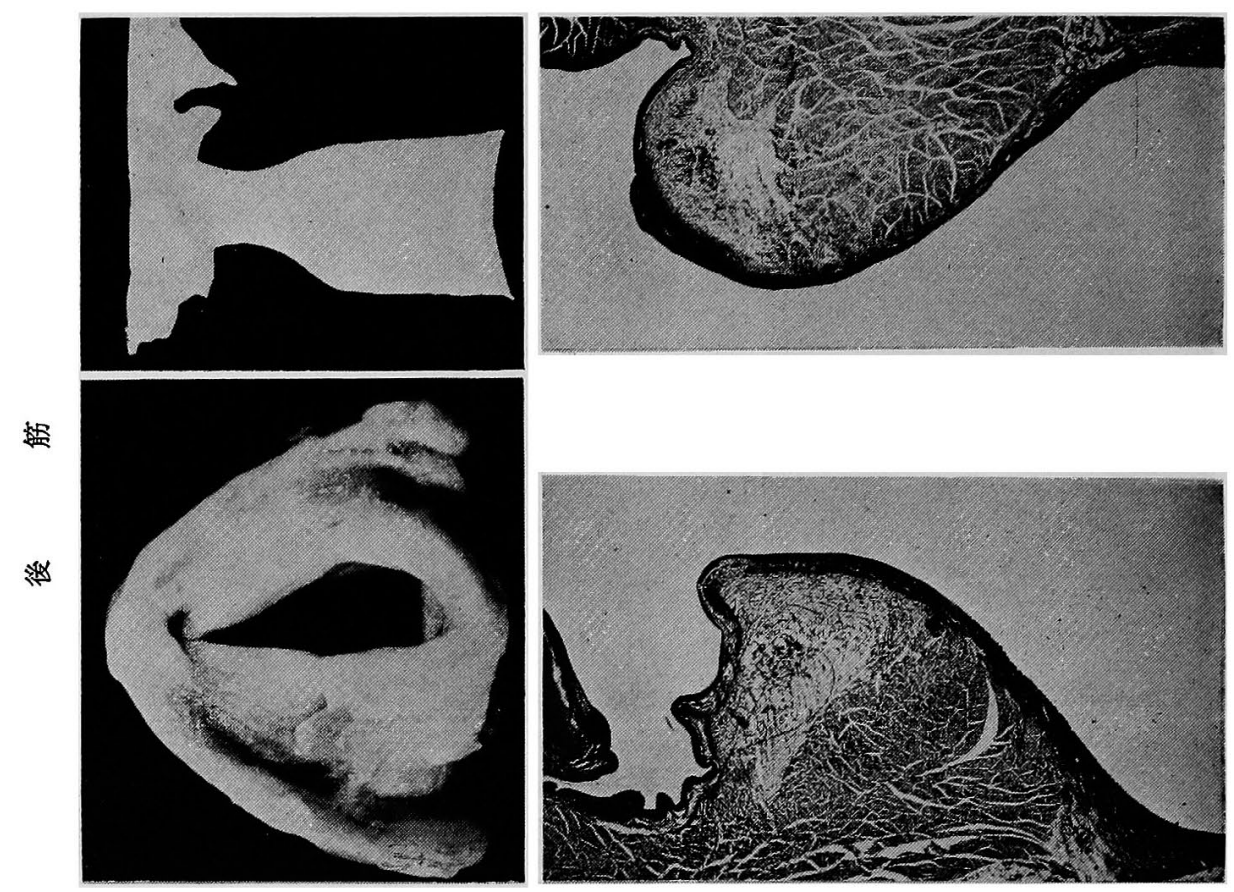

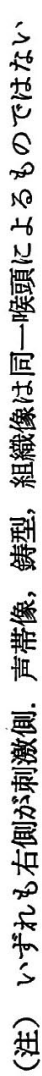
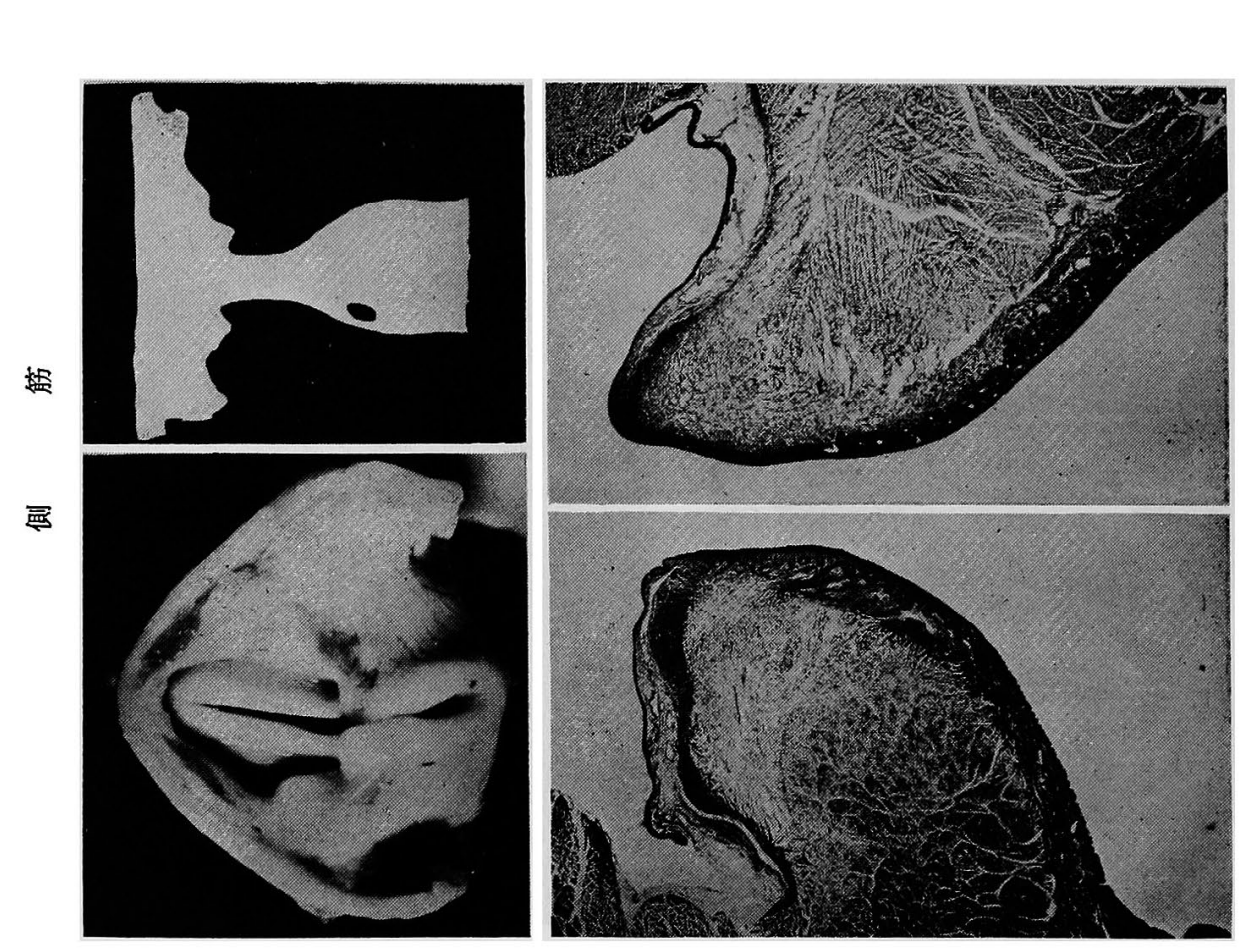
機能は単純なものではなく，協調的な複雑な調節機構に よつて遂行されているものであり，今後ともさらにあら ゆる方面からの研究がなされなければならない

\section{参考文献}

1) 平野实：歌声の調節機躈. 音声言語 医 学, $11 ; 1$, 1970.

2) 平野実: 発声中の声带. 医学のあ沈み, $80 ； 622$, 1972.

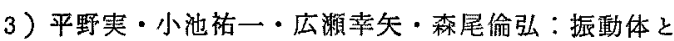
しての声帯の橉造。日耳舆，76；1341，1973.

4）云瀨籊：声門鎖筋の機能分化. 日耳舅， $77 ； 46$, 1974.

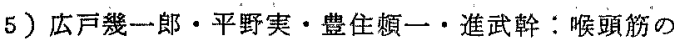
機能。耳罳臨床, $57 ; 1,1964$.

6）広戸幾一郎：発声機桠の面からみた喉頭の病熊生 理。耳鬼臨床, $59 ； 229,1966$.

7) 広戸幾一郎：“喉頭の比較解剖生理. 耳鼻㸶喉科“学 (後藤敏郎監修)，下巻，医学畫院，1971.

8）岩村忍：喉頭内筋の機能区分。音声言語医学，15; $77,1974$.

9）小池祐一・平野実・森尾倫弘・粕谷尚男：声带の形 態之内喉頭筋。音声言語医学，14；29, 1973.

10) Lemere, F.: Innervation of the larynx, I. Inner vation of the laryngeal muscles. Am. J. Anant., 51; 417, 1932.

11) Lemere, F.: Innervation of the larynx, III. Experimental paralysis of the laryngeal nerve. Arch. Otolaryng., $18 ; 413,1933$.

12）村上泰：後輸状披裂筋反射と乞の生理的意義。日耳 舀, 74；1263，1971.

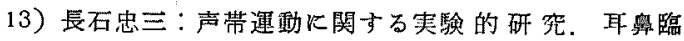
床, $33 ; 518,1938$.

14）高㖽腈朗：哺乳動物内喉頭筋及び喉頭関節の比較解 剖生理学的研究。耳聯, 10（補 1)；18，1964.

15）竹之内智：喉頭神経刺㦸に上る声門運動水関する研 究。耳鼻臨床，56；398，1963。

16）牛島達次郎：喉頭笳の機械的収縮特性飞関する実験 的研究。日耳留，71；1494，1968.

17) Vogel, P.H.: The innervation of the larynx of man and the dog. Am. J. Anant., 90; 427, 1952.

本論文の要旨は第18回日本音声言語医学会総会 $(1973$, 東京) および第16回国際音声言語医学会 (1974, インタ ーラーケン)に於てロ演した。

(原稿受付 昭和50.6.19日急载) 